\title{
ENHANCED DOE HIGH-LEVEL WASTE MELTER THROUGHPUT STUDIES: SRNL GLASS SELECTION STRATEGY
}

F.C. Raszewski

T.B. Edwards

D.K. Peeler

January 2008

Process Science and Engineering Section Savannah River National Laboratory Aiken, SC 29808 
WSRC-STI-2007-00652

Revision 0

\section{DISCLAIMER}

This report was prepared by Washington Savannah River Company (WSRC) for the United States Department of Energy under Contract No. DE-AC09-96SR18500 and is an account of work performed under that contract. Neither the United States Department of Energy, nor WSRC, nor any of their employees makes any warranty, expressed or implied, or assumes any legal liability or responsibility for the accuracy, completeness, or usefulness, of any information, apparatus, or product or process disclosed herein or represents that its use will not infringe privately owned rights. Reference herein to any specific commercial product, process, or service by trademark, name, manufacturer or otherwise does not necessarily constitute or imply endorsement, recommendation, or favoring of same by WSRC or by the United States Government or any agency thereof. The views and opinions of the authors expressed herein do not necessarily state or reflect those of the United States Government or any agency thereof.

\begin{tabular}{|c|}
\hline Printed in the United States of America \\
Prepared For \\
U.S. Department of Energy
\end{tabular}

The Savannah River National Laboratory is operated for the U.S. Department of Energy by Washington Savannah River Company. 
Keywords: waste loading, $D W P F$, high level waste

Retention: permanent

\section{ENHANCED DOE HIGH-LEVEL WASTE MELTER THROUGHPUT STUDIES: SRNL GLASS SELECTION STRATEGY}

F.C. Raszewski

T.B. Edwards

D.K. Peeler

January 2008

Process Science and Engineering Section Savannah River National Laboratory Aiken, SC 29808

Prepared for the U.S. Department of Energy Under Contract Number DEAC09-96SR18500

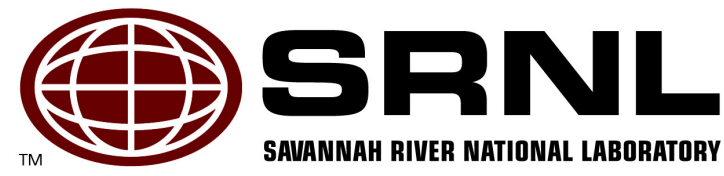




\section{REVIEWS AND APPROVALS}

\section{AUTHORS:}

F.C. Raszewski, Process Science and Engineering Section

Date

T.B. Edwards, Statistical Consulting Section

Date

D.K. Peeler, Process Science and Engineering Section

Date

\section{TECHNICAL REVIEWER:}

K.M. Fox, Process Science and Engineering Section

Date

\section{APPROVERS:}

D.A. Crowley, Manager, Stabilization Science Research Group

Date

R.E. Edwards, Manager, Process Science and Engineering Section

Date

PC Suggs, DOE - SRS/AMWDP

Date

Technology Development Lead 
WSRC-STI-2007-00652

Revision 0

\section{EXECUTIVE SUMMARY}

The Department of Energy has authorized a team of glass formulation and processing experts at the Savannah River National Laboratory (SRNL), the Pacific Northwest National Laboratory (PNNL), and the Vitreous State Laboratory (VSL) at Catholic University of America to develop a systematic approach to increase high level waste melter throughput (by increasing waste loading with minimal or positive impacts on melt rate). This task is aimed at proof-of-principle testing and the development of tools to improve waste loading and melt rate, which will lead to higher waste throughput. Four specific tasks have been proposed to meet these objectives (for details, see WSRC-STI-2007-00483): 1) Integration and Oversight, 2) Crystal Accumulation Modeling (led by PNNL)/Higher Waste Loading Glasses (led by SRNL), 3) Melt Rate Evaluation and Modeling, and 4) Melter Scale Demonstrations.

Task 2, Crystal Accumulation Modeling / Higher Waste Loading Glasses is the focus of this report. The objective of this study is to provide supplemental data to support the possible use of alternative melter technologies and/or implementation of alternative process control models or strategies to target higher waste loadings (WLs) for the Defense Waste Processing Facility (DWPF) - ultimately leading to higher waste throughputs and a reduced mission life.

The glass selection strategy discussed in this report was developed to gain insight into specific technical issues that could limit or compromise the ability of glass formulation efforts to target higher WLs for future sludge batches at the Savannah River Site (SRS). These technical issues include Al-dissolution, higher $\mathrm{TiO}_{2}$ limits and homogeneity issues for coupled-operations, $\mathrm{Al}_{2} \mathrm{O}_{3}$ solubility, and nepheline formation. To address these technical issues, a test matrix of 28 glass compositions has been developed based on 5 different sludge projections for future processing. The glasses will be fabricated and characterized based on the protocols outlined in the SRNL Task and Quality Assurance (QA) plan. 


\section{TABLE OF CONTENTS}

LIST OF TABLES ....................................................................................... vii

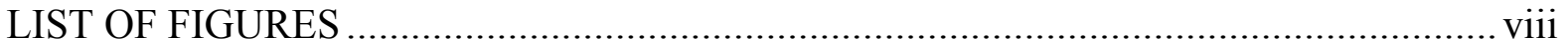

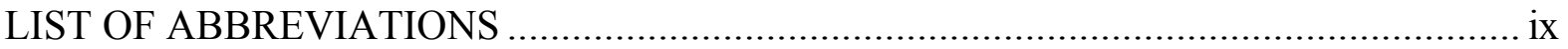

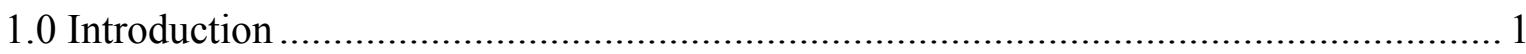

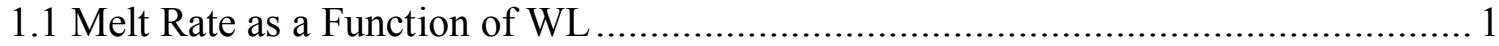

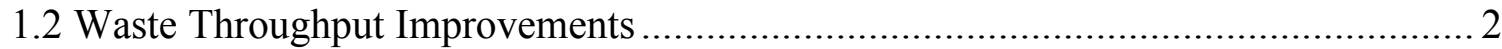

1.2.1 Strategic Glass Formulation.................................................................... 3

1.2.2 Alternative Melter Technology ....................................................... 4

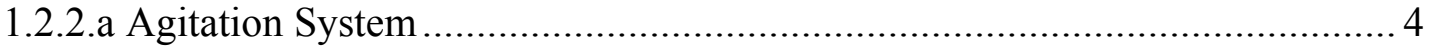

1.2.2.b Cold Crucible Induction Melter (CCIM) Technology .............................. 5

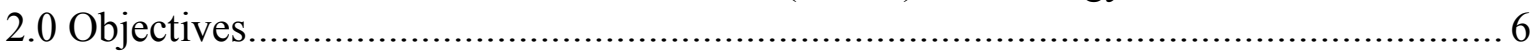

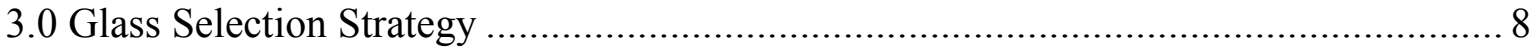

3.1 Glass Systems with WL Restricted by $\mathrm{T}_{\mathrm{L}}$ Model Predictions ................................ 8

3.2 Glass Systems for Coupled Operations Showing Select WL Restrictions ............... 11

3.3 Glass Systems with WL Restrictions due to High $\mathrm{Al}_{2} \mathrm{O}_{3}$ Content ........................ 13

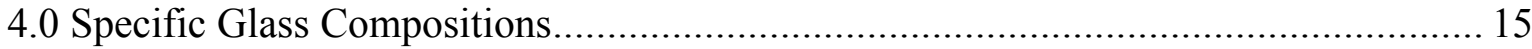

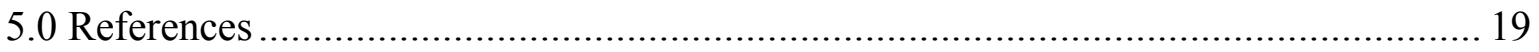




\section{LIST OF TABLES}

Table 1. Nominal Sludge Compositions of Cluster 2 and Cluster 4 (wt \%)...................... 10

Table 2. Cluster 2 Average and Cluster 4 Average MAR Results .................................. 10

Table 3. Nominal Sludge Compositions of MSP-001/SB8 and MSP-001/SB9 (wt\%) ........ 12

Table 4. MSP-001/SB8 and MSP-001/SB9 MAR Results ........................................ 12

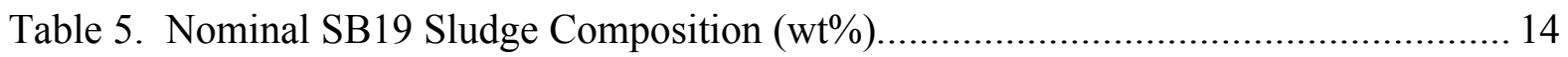

Table 6. Without Aluminum Dissolution WOALD - SB19 MAR Results ........................ 14

Table 7. Non-Radioactive Compositions (wt percent) of Test Matrix 2 Glasses................. 16

Table 8. Non-Radioactive Compositions (wt percent) of Test Matrix 2 Glasses................. 17

Table 9. Radioactive Compositions (wt percent) of Test Matrix 2 Glasses ...................... 18 


\section{LIST OF FIGURES}

Figure 1. Melt rate and waste throughput as a function of waste loading for SB3.............. 2

Figure 2. Waste throughput improvements due to strategic glass formulation..................... 3

Figure 3. Melt rate improvements as a result of alternative melter technologies. ............... 4 


\section{LIST OF ABBREVIATIONS}

\begin{tabular}{|c|c|}
\hline ARP & Actinide Removal Process \\
\hline $\mathrm{CCC}$ & Centerline Canister Cooled \\
\hline CCIM & Cold Crucible Induction Melter \\
\hline CSSX & Caustic Side Solvent Extraction \\
\hline CST & Crystalline Silicotitanate \\
\hline DOE & Department Of Energy \\
\hline DWPF & Defense Waste Processing Facility \\
\hline EPRR & Enhanced Processing Radionuclide Removal \\
\hline HLW & High-Level Waste \\
\hline JHM & Joule Heated Melter \\
\hline LWO & Liquid Waste Organization \\
\hline MAR & Measurement Acceptability Region \\
\hline MCU & Modular CSSX Unit \\
\hline MSP & Modular Salt Processing \\
\hline MST & Monosodium Titanate \\
\hline PAR & Property Acceptability Region \\
\hline PCCS & Product Control Composition System \\
\hline PCT & Product Consistency Test \\
\hline PNNL & Pacific Northwest National Laboratory \\
\hline QA & Quality Assurance \\
\hline $\mathrm{RF}$ & Resorcinol Formaldehyde \\
\hline SB & Sludge Batch \\
\hline SME & Slurry Mix Evaporator \\
\hline SMR & Sludge Mass Reduction \\
\hline SRNL & Savannah River National Laboratory \\
\hline SRS & Savannah River Site \\
\hline VSL & Vitreous State Laboratory \\
\hline WL & Waste Loading \\
\hline WOALD & Without Aluminum Dissolution \\
\hline wt & Weight \\
\hline WTP & Waste Treatment and Immobilization Plant \\
\hline
\end{tabular}




\subsection{Introduction}

High-level waste (HLW) throughput (i.e., the amount of waste processed per unit time) is a function of two critical parameters: waste loading (WL) and melt rate. For the Waste Treatment and Immobilization Plant (WTP) at the Hanford Site and the Defense Waste Processing Facility (DWPF) at the Savannah River Site (SRS), increasing HLW throughput would significantly reduce the overall mission life cycle costs for the Department of Energy (DOE).

Significant increases in waste throughput have been achieved at DWPF for Sludge Batch 3 (SB3) and Sludge Batch 4 (SB4). Key technical and operational initiatives that supported the waste throughput improvement included improving or maximizing facility attainment, improving the Chemical Processing Cell (CPC) flowsheet, performing critical reviews and improving the process control models, and improving frit formulations. With respect to strategic glass formulation efforts, frit development has shifted from a global "one frit fits all" concept to a focused effort on optimizing frits for specific sludge batches. This strategy has allowed DWPF to target higher WLs while maintaining or improving melt rate - which in turn has been a significant contributor to the improved waste throughputs obtained in the facility.

As a result of these key initiatives, DWPF increased WLs from a nominal 28\% (with SB2) to $\sim 38 \% \mathrm{WL}$ while maintaining or slightly improving canister fill times for SB3. Although significant improvements in waste throughput were obtained, the process control models did allow DWPF to target higher WLs (i.e., $40 \%$ and greater); however, actual facility data have shown that melt rate is significantly reduced at these higher WLs, thus adversely impacting waste throughput. Therefore, DWPF evaluated (and plans to evaluate) melt rate as a function of WL for each sludge batch to determine the WL that yields the maximum throughput. For SB3, optimum waste throughput was demonstrated at a WL significantly lower than that allowed by the process control models. Narrowing or eliminating this WL gap is of interest for continual improvements in the DWPF process. Additional background information is provided in the following sections, prior to the discussion of the glass selection strategy, to describe various approaches for improving DWPF WL and melter throughput.

\subsection{Melt Rate as a Function of WL}

The general trend of melt rate versus WL observed for SB3 is conceptually shown in Figure 1. For the Frit 418 - SB3 system, the projected operating window (i.e., the WL interval over which the glass is classified as acceptable based on model predictions) was approximately 25 - 45\% WL. Predictions associated with liquidus temperature $\left(\mathrm{T}_{\mathrm{L}}\right)$ limited access to higher WLs. For example, glasses having a $46 \% \mathrm{WL}$ or higher were predicted to have $\mathrm{T}_{\mathrm{L}} \mathrm{S}$ greater than the Product Composition Control System (PCCS) constraint (nominally $1050^{\circ} \mathrm{C}$ without uncertainties). ${ }^{\mathrm{a}}$ SRNL and subsequent radioactive operations at DWPF evaluated melt rate as a function of WL for this system and found a gradual decrease in melt rate with increased

\footnotetext{
${ }^{a}$ The $\mathrm{T}_{\mathrm{L}}$ constraint is based on a nominal melt temperature of $1150^{\circ} \mathrm{C}$. The Property Acceptability Region (PAR) value for acceptability is $1050^{\circ} \mathrm{C}$, which provides a $100^{\circ} \mathrm{C}$ safety factor relative to the $1150^{\circ} \mathrm{C}$ nominal melt temperature. This constraint eliminates bulk devitrification or crystallization within the melt pool.
} 
WL (represented by the red line in Figure 1). The maximum waste throughput was determined to be at approximately 38\% WL for the Frit 418 - SB3 system (represented by "peak" in the blue line of Figure 1). Although the process control models allowed WLs up to $45 \%$ to be targeted, the severe negative impact of melt rate at these higher WLs resulted in a reduction of targeted WLs in order to maximize waste throughput. Thus, for SB3 a 7 percentage point WL interval (39 to $45 \% \mathrm{WL}$ - see shaded area in Figure 1) was not targeted due to significant reductions in melt rate. It should be noted that if one were only concerned with minimizing the number of canisters produced, glasses targeting the highest WL allowed by the process control models would achieve that goal (e.g., for the Frit 418 - SB3 system, WLs of $45 \%$ would have met this objective). Based on this strategy and historical melt rate trends, canister fill times would increase leading to a longer mission life. Targeting maximum waste throughput should allow both tank farm and DWPF operations to be terminated sooner; however, this strategy does not minimize the canister count.

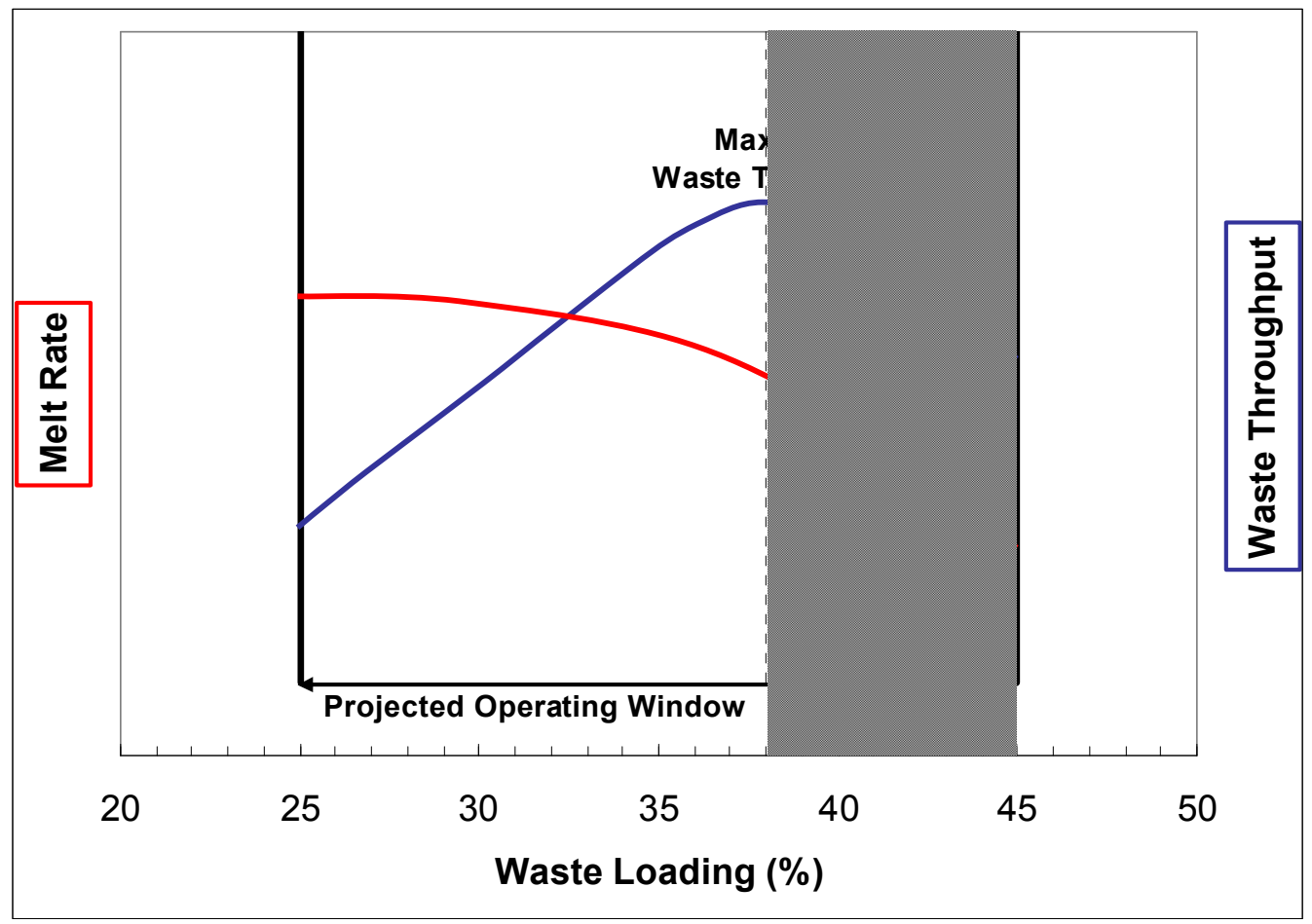

Figure 1. Melt rate and waste throughput as a function of waste loading for SB3.

\subsection{Waste Throughput Improvements}

Although processing SB3 at 38\% WL (point of maximum waste throughput) was a significant improvement over the nominal 28\% WL during DWPF's early processing, the ability to access higher WLs becomes a critical focus area for continuous improvement. Use of alternative approaches to attain higher waste throughputs, either chemically through frit development or physically by a change in melter, has the potential to reduce (or eliminate) the negative trends observed in melt rate versus WL. These alternative approaches are conceptually presented and discussed below because they provide the basis for the glass selection strategy used for the current study. 


\subsubsection{Strategic Glass Formulation}

Figure 2 provides a conceptual view of strategic glass formulation efforts to shift the maximum waste throughput from $38 \%$ WL to some higher WL value. ${ }^{b}$ In this example, the dashed red line is the result of glass formulation activities that have developed critical or strategic compositional regions, which improve the relationship between melt rate and WL. Glass formulation activities could result in the identification of a key frit component that improves melt rate while maintaining the ability to target higher WL. In this example,DWPF could target a $42 \% \mathrm{WL}$, thus gaining access to the $7 \%$ interval in WL that is currently restricted due to waste throughput incentives (as shown by the shaded region in Figure 2). As a result, higher waste throughputs could be obtained reducing overall mission life. Although this scenario does not completely eliminate the 7\% restricted WL window, shifting the throughput peak $1-2$ percentage points in WL would be a significantly positive impact for DWPF. If glass formulation efforts could result in the maximum throughput being obtained at the maximum allowable WL from a model perspective $(45 \% \mathrm{WL}$ in the current example), then there would be incentive to challenge model predictions. Efforts to revise or develop new models may be warranted if the maximum in waste throughput for a specific glass forming system occurs at a WL greater than allowed by PCCS. Otherwise, there is no incentive to modify the current modeling approach given no change in melter technology.

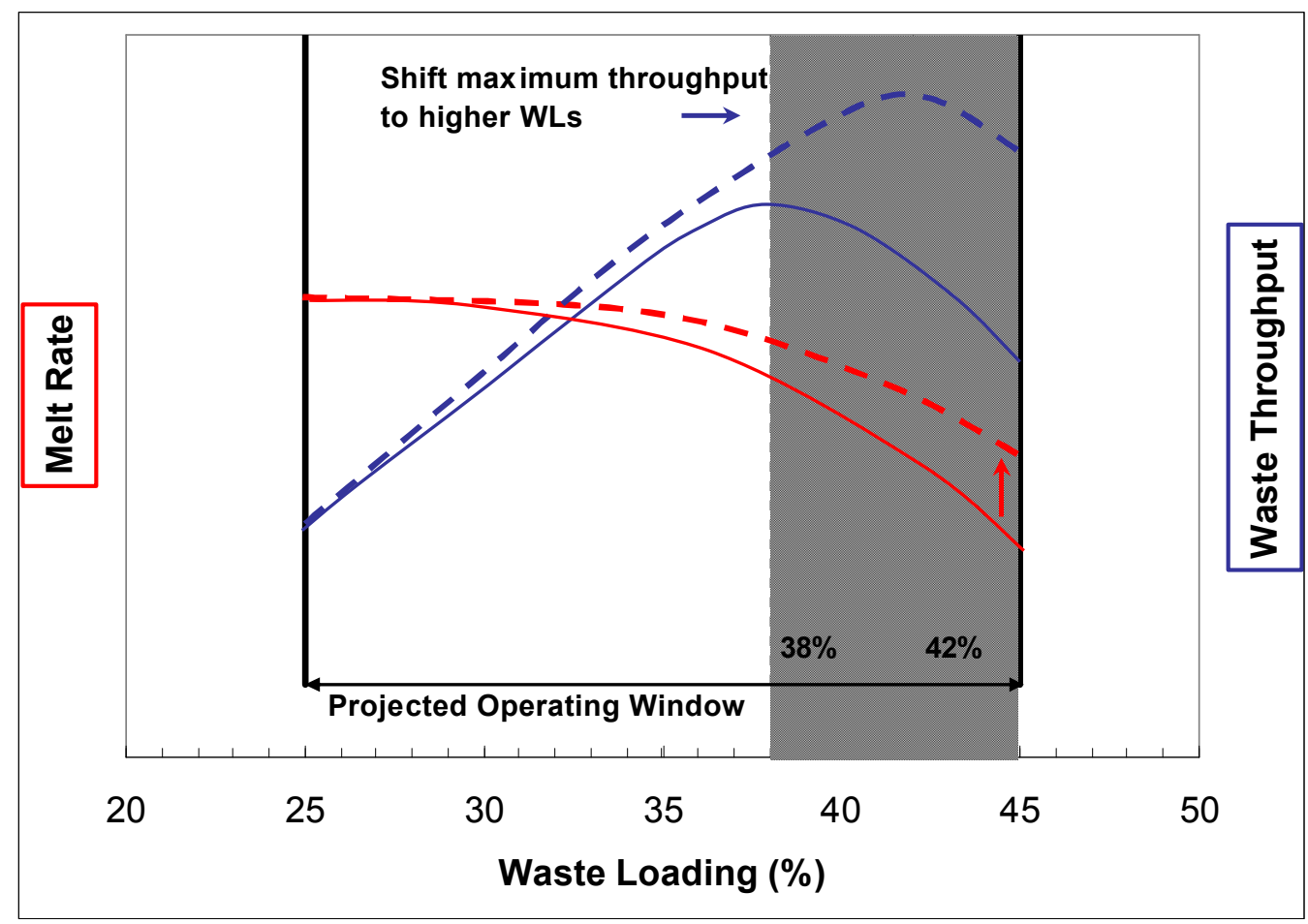

Figure 2. Waste throughput improvements due to strategic glass formulation.

\footnotetext{
${ }^{\mathrm{b}}$ In the case of Frit $418-\mathrm{SB} 3$, the system becomes $\mathrm{T}_{\mathrm{L}}$ limited at $46 \% \mathrm{WL}$.
} 


\subsubsection{Alternative Melter Technology}

Another option to improve waste throughput is to implement a new melter technology. Assuming that a new melter technology essentially eliminates the dependence of melt rate on WL, melt rate could be represented by the flat dashed red line shown in Figure 3. Conceptually, maximum waste throughputs would then be limited by model predictions to 45\% WL (using the Frit 418 - SB3 system as the example) under the current Joule Heated Melter (JHM) technology and the continued use of current process control strategies (i.e., implementation of a "true" $T_{L}$ limit) - see gray shaded region of Figure 3. Implementation of new models, alternative melter technologies that allow higher melt temperatures, and/or alternative processing strategies (i.e., vol\% crystallization approach being led by PNNL as part of this overall task) have the potential to allow WLs greater than those allowed by current model predictions to be targeted. These options and possible impacts to targeting higher WL are discussed below.

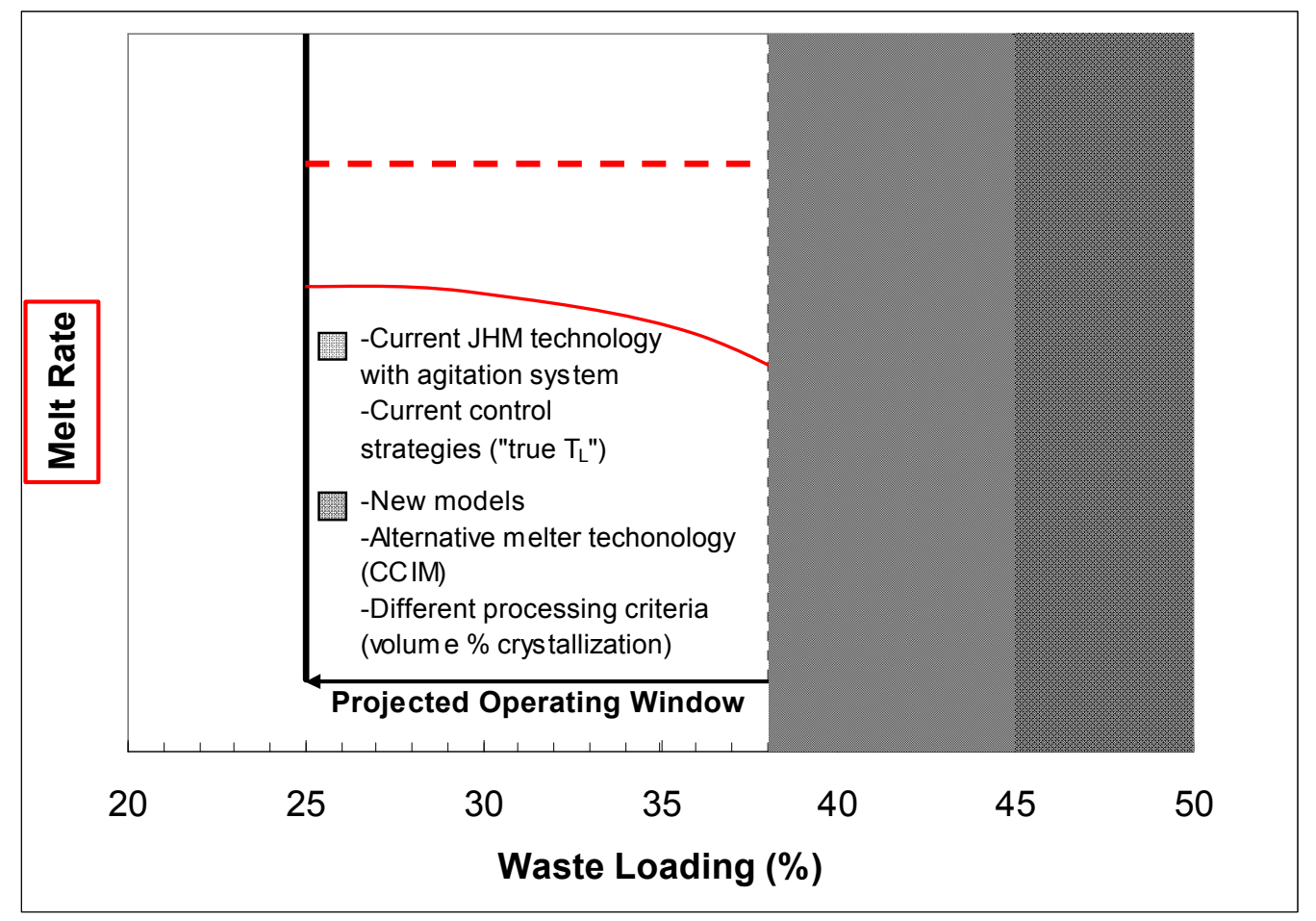

Figure 3. Melt rate improvements as a result of alternative melter technologies.

\subsection{2. a Agitation System}

The introduction of an agitation system (bubbler or stirrer) within the current JHM technology would provide forced convection, potentially leading to significant improvements in melt rate. In this scenario, the assumption is that historical trends between melt rate and WL are overcome by the forced convection that would allow DWPF to target higher WLs to maximize waste throughput. Even with an agitation system added to the current JHM technology, DWPF would become limited at some higher WLs based on current process control models and/or strategies. Although significant improvements in waste throughput 
could be demonstrated up to that PCCS limited WL, the driver for targeting higher WLs would shift from being melt rate restricted to model or process control strategy limited. If true, then options to gain further improvement in waste throughput would fall into two categories: (a) revisions to reduce conservatism in existing models or development of new models, and/or (b) developing and implementing new processing criteria.

First consider the possibility that the current models are conservative (category (a) as listed above). For the Frit 418 - SB3 system (Figure 3), the $\mathrm{T}_{\mathrm{L}}$ model would limit access to WLs greater than $45 \%$ regardless of the mechanism that yielded higher melt rates. In order to target even higher WLs, one would have to demonstrate that the current model is conservative. If model predictions were determined to be greater than measured values through an experimental study, one of three actions could be taken to access to higher WLs: (1) revision of the current model to further reduce uncertainties, (2) development of a new model, or (3) use of other existing $\mathrm{T}_{\mathrm{L}}$ models. These options would still utilize the current process control strategy criteria (e.g., implementation of a "true $\mathrm{T}_{\mathrm{L}}$ " constraint); only the revised or alternate model would allow for higher WLs to be targeted. Implementation of a new or revised model with an agitation system could lead to significant improvements in waste throughput. This approach would be very similar to the situation shown in Figure 2, in which strategic glass formulation causes maximum throughput to occur at the maximum allowable WL based on model predictions.

Next, consider option (b) as listed above (developing and implementing new process related criteria). A critical criterion of the current process control strategy is the elimination of bulk devitrification within the melt pool. This leads to the implementation of a "true $\mathrm{T}_{\mathrm{L}}$ " constraint and the application of both measurement and property uncertainties. Although an effective and technically defensible approach, one could either remove some of the conservatism in the current approach (e.g., change the $100^{\circ} \mathrm{C}$ delta between $T_{M}$ and $T_{L}$ to $50^{\circ} \mathrm{C}$ ) or implement the less conservative approach being developed by WTP. Instead of implementing a "true $\mathrm{T}_{\mathrm{L}}$ " constraint for HLW processing, WTP's approach is to allow a limited volume fraction of crystallization to occur within the melt pool. The use of bubblers should help suspend the crystals allowing for higher WLs to be targeted while minimizing the negative impacts to glass processing (alternatively sloped bottom melters may be utilized). Although this approach does increase risks, it is another alternative that could allow higher WLs to be targeted. This approach would require the development of a new model that relates volume percent crystallization to temperature for the compositional regions of interest. It should be noted that the authors are not recommending this option be adopted at DWPF. From an integration perspective, it is mentioned in this report as this EM-20 task does include glass formulation work by PNNL (being supported by SRNL) in support of a limited volume percent crystallization strategy. ${ }^{1}$

\subsection{2.b Cold Crucible Induction Melter (CCIM) Technology}

A second option, which could essentially eliminate (or minimize) the dependence of melt rate on WL, is the CCIM technology that not only offers the potential for an agitation system (bubblers and/or stirrers), but a possible additional advantage of higher processing temperatures $\left(>1150^{\circ} \mathrm{C}\right)$ relative to the current $\mathrm{JHM}$ technology. The higher processing 
temperatures would allow DWPF to target higher WLs, which typically result in higher $\mathrm{T}_{\mathrm{L}}$ values while maintaining the current "true $\mathrm{T}_{\mathrm{L}}$ " processing strategy. One issue to be addressed is the applicability of the current $\mathrm{T}_{\mathrm{L}}$ model at these higher WLs. If the model was not developed over a compositional region of interest at higher WLs, then revisions to the current model or development of a new model would be required in order for DWPF to realize the maximum waste throughputs considered under this scenario. Recent glass formulation efforts by SRNL to explore the use of the CCIM technology for DWPF have shown that it is feasible to process DWPF-type sludges at significantly higher WLs $(>50 \%){ }^{2}$ During these high WL tests, which were conducted at a nominal melt temperature of $1250^{\circ} \mathrm{C}$, there were potential issues associated with the performance and applicability of DWPF's current process control models - in particular the $\mathrm{T}_{\mathrm{L}}$ model. These models have been effectively utilized to support glass systems representing a lower interval of WLs being processed at the JHM's operating temperature of $1150^{\circ} \mathrm{C}$. The performance issues with the current DWPF process control models bring into question their ability to serve as a guide for the frit development efforts supporting higher WL glass systems to be processed at the CCIM's higher melt temperature. To gain a better understanding of these issues, additional experimental data would be necessary. The CCIM technology may also offer the possibility to implement the less conservative approach by allowing some limited volume fraction of crystallization within the melter.

Regardless of the approach, either chemically through frit development strategies or physically through the implementation of an alternative melter technology, the ability to target higher WLs without negatively impacting melt rate is a significant driver to reduce overall life cycle costs of the DWPF. Strategic initiatives have been identified with strategic glass formulation efforts (or basic compositional - property data), which may provide a key input to make incremental or step function changes to the waste throughput equation. New melter technologies, coupled with glass formulation efforts, have been identified as possible solutions to overcome the waste throughput barriers currently being experienced in DWPF. The objective of this task is to identify glass formulation strategies that would allow access to higher WLs for future HLW processing at DWPF. Identifying technical issues that would prevent targeting higher WLs is also critical as it provides direction to focus future glass formulation or model development activities in support of continuous improvement. It should be noted that future sludge batches may have troublesome components that overly restrict DWPF's ability to target WLs that are currently deemed reasonable or acceptable.

\subsection{Objectives}

It has been proposed that a team of glass formulation and processing experts at Pacific Northwest National Laboratory (PNNL), SRNL, and the Vitreous State Laboratory (VSL) at Catholic University of America develop a systematic approach to increase HLW throughput (by increasing WL with minimal or positive impacts on melt rate). ${ }^{3}$ Programmatically, this task is aimed at proof-of-principle testing and the development of tools to improve waste loading and melt rate, which will lead to higher waste throughput. The following four specific tasks have been proposed to meet this programmatic objective: 1) Integration and Oversight, 2) Crystal Accumulation Modeling (led by PNNL)/Higher Waste Loading Glasses 
(led by SRNL), 3) Melt Rate Evaluation and Modeling, and 4) Melter Scale Demonstrations. The details of these tasks can be found in WSRC-STI-2007-00483. ${ }^{4}$

The current study is focused on Task 2 (crystal accumulation modeling and higher waste loading glasses) and involves glass formulation and physical property testing by both PNNL and SRNL (as defined in the PNNL and SRNL test plans). ${ }^{1,4}$ The primary objectives of Task 2 are as follows:

1. Develop less conservative and technically sound constraints for Hanford HLW glass formulations to avoid the deleterious effects of crystal accumulation in melters. This objective is being primarily addressed through the glass selection strategy developed by PNNL. A discussion of PNNL's development of "Test Matrix 1" glass compositions in support of crystal accumulation modeling, which are primarily of interest to the WTP at Hanford, may be found in EMHLW-TP-07-01. ${ }^{1}$ Although driven by Hanford formulations, these data are also of interest to DWPF (as discussed in Section 1.2.2).

2. Assess alternative glass formulation strategies to improve WL for DWPF HLW glass using the existing JHM technology.

3. Assess alternative glass formulation strategies to improve WL for DWPF HLW glass using alternative melter technologies leading to process control model development.

4. Assess the potential conservatism in the current process control models that may limit the ability to target relatively high WLs for coupled operations. ${ }^{c}$

The objective of this study is to provide supplemental data to support the possible use of the current JHM and/or alternative melter technologies to target higher WLs (objectives 3 and 4 above) for future DWPF sludge processing. It should be noted that the option of strategic frit development efforts for the existing JHM melter technology (objective 2 above) is not currently being addressed in this study. ${ }^{\mathrm{d}}$

Two glass composition test matrices have been developed to address the objectives of this task. As mentioned above, PNNL has developed "Test Matrix 1" in support of crystal accumulation modeling for WTP at Hanford. ${ }^{1}$ The current document specifically addresses the glass selection strategy leading to compositions that define SRNL's "Test Matrix 2" for higher waste loading glasses. Although the PNNL and SRNL matrices are focused on different waste streams, the data collected from each study will be mutually beneficial.

\footnotetext{
c SB4 with the Actinide Removal Process (ARP) / monosodium titanate (MST) and/or Modular Caustic-Side Solvent Extraction (CSSX) Unit (MCU).

${ }^{d}$ An alternative solution to target higher WLs for the current JHM technology would be to identify strategic frit formulations (i.e., frit additives currently not being considered) that would overcome the historical trends of a decreased melt rate with increased WL. To develop a strategic path forward, a meeting among SRNL, PNNL, and VSL glass scientists was planned to brainstorm possible solutions. ${ }^{3}$ This meeting has not yet occurred and therefore this objective has not been integrated into the glass selection strategy presented in this report.
} 


\subsection{Glass Selection Strategy}

The glass selection strategy for the "Test Matrix 2" glasses will focus on specific technical issues that have been identified for future DWPF sludge batches that would either overly restrict WLs or challenge the current model predictions in order to gain access to higher WLs than currently allowed. As will be discussed, future sludge batch projections will be utilized to identify the glass formulation issues. The results of this task will identify possible solutions to pursue as higher WLs are targeted.

These technical issues may be investigated by considering:

1. Glass systems with WLs restricted by $\mathrm{T}_{\mathrm{L}}$ predictions.

2. Glass systems for coupled operations showing select WL restrictions $\left(\mathrm{TiO}_{2}\right.$ (solubility and model applicability), low frit, and homogeneity predictions).

3. Glass systems with WL restrictions due to high $\mathrm{Al}_{2} \mathrm{O}_{3}$ content.

To address these items, a test matrix of 28 glass compositions was developed for five different sludge types. ${ }^{\mathrm{e}}$ The glasses were selected to challenge a specific technical concern through the failure of one (or more) PCCS related constraints as described in the next three sub-sections. The selection of the glasses was also determined to be those that would provide supplemental data to support the alternatives being considered for waste throughput improvements.

\subsection{Glass Systems with WL Restricted by $T_{L}$ Model Predictions}

In an effort to reduce overall mission life, one of the strategies that may be utilized by the Liquid Waste Organization (LWO) is the implementation of aluminum dissolution, which removes some fraction of aluminum from the waste and reduces the overall mass to be immobilized at DWPF. The impacts of aluminum dissolution are being considered at SRNL as directed by Peeler et al. and as investigated by Newell et al. under the Sludge Mass Reduction (SMR) task. ${ }^{5,6}$ The primary focus of the SMR task is to assess melt rate and/or waste throughput differences for flowsheets with and without Al-dissolution. Newell et al. have selected frit compositions to support this task based upon (a) assessments of their projected operating windows (when combined with the sludge compositions) and (b) variations in the frit compositions that should provide insight into melt rate differences as a function of WL. ${ }^{5}$ The results of the SMR task are intended to: (1) gain a better understanding of the potential impacts of high-temperature, Al-dissolution on DWPF operations within the current projected operating windows, and (2) gain a more fundamental understanding of the impacts of WL on melt rate for situations with and without Al-dissolution. The scope of the SMR task does not attempt to identify or address any potential technical issues associated with attaining WLs beyond those currently allowed by PCCS, assuming that there are no

\footnotetext{
${ }^{\mathrm{e}}$ The test matrix is comprised of 22 non-radioactive and 6 radioactive glasses. As will be discussed, the six radioactive glasses were chosen to gain insight into the low frit and homogeneity issues associated with coupled operations, which could not be assessed using their non-radioactive, counterpart glasses.
} 
changes to the current melter technology or process control algorithms that may lead to higher WLs beyond those defined by the current models. Although higher WLs are outside the scope of the SMR task, the projected sludge compositions utilized are of interest for the current study because they represent sludges both with and without Al-dissolution. Identifying glass compositions, using sludge projections from the SMR task, that are solely $\mathrm{T}_{\mathrm{L}}$ limited at higher WLs, is of interest in the current study in order to enhance the understanding of the potential benefits of alternative melter technologies for DWPF or gain insight into potential conservatism of current models.

Newell et al. developed two average sludge compositions based on the fourteen sludge batches without Al-dissolution and twelve sludge batches with Al-dissolution identified as input for the SMR task. ${ }^{5,6}$ These average compositions, designated as Cluster 2 (representing, in general, sludge batches without Al-dissolution) and Cluster 4 (representing, in general, sludge batches with Al-dissolution) are given in Table 1. For each of these two average compositions, two frits were identified that lead to unacceptable $\mathrm{T}_{\mathrm{L}}$ predictions at WLs of $45 \%$ and 50\% - all other properties are classified as acceptable. Table 2 shows the measurement acceptability region (MAR) criteria that fail at $45 \%$ and $50 \%$ WL for each system of interest. Predictions of $\mathrm{T}_{\mathrm{L}}$ would limit access to these higher WLs using the current JHM technology and MAR acceptance criteria. In Table 2, MAR predictions are provided for glass compositions with and without $\mathrm{U}_{3} \mathrm{O}_{8}$ and $\mathrm{ThO}_{2}$. Removal of these two components from the glass compositions does not change the MAR results (see last column of Table 2). That is, all of the non-radioactive glasses fail the $\mathrm{T}_{\mathrm{L}}$ criterion - consistent with the results of their radioactive counterparts. To minimize personnel exposure, $\mathrm{U}_{3} \mathrm{O}_{8}$ and $\mathrm{ThO}_{2}$ will be removed from the targeted compositions (i.e., the targeted compositions will be normalized without $\mathrm{U}_{3} \mathrm{O}_{8}$ and $\mathrm{ThO}_{2}$ ).

The low viscosity constraint also fails at the MAR for both frit compositions with Cluster 4 at a WL of $50 \%$. This is not a concern with respect to the objectives of this study. Because viscosities of the "Test Matrix 2" glasses are to be measured, there is an opportunity to compare measured and predicted viscosities at higher WLs, assuming that crystallization does not impede or influence the viscosity measurements. The data would also be an indication of the current model's ability to predict viscosity at higher processing temperatures (i.e., a nominal processing temperature of $1250^{\circ} \mathrm{C}$ is necessary for CCIM technology). ${ }^{\mathrm{f}}$

Fabrication and testing of these glasses (non-radioactive) will provide insight to the applicability of the current $\mathrm{T}_{\mathrm{L}}$ model at these higher WLs (i.e., predicted versus measured $\mathrm{T}_{\mathrm{L}} \mathrm{s}$. If the durability of such high WL glasses is acceptable and predictable, characterization of these glasses could provide supplemental data and incentive to pursue alternative melter technologies or process control strategies. In addition, these data would add to the limited composition - property database for glasses targeting higher WLs from which models may need to be developed or revised.

\footnotetext{
${ }^{\mathrm{f}}$ Because the current viscosity model predicts viscosity of the glass system at $1150^{\circ} \mathrm{C}$, adjustments to the model would be required prior to making comparisons at higher temperatures.
} 
WSRC-STI-2007-00652

Revision 0

Table 1. Nominal Sludge Compositions of Cluster 2 and Cluster 4 (wt \%)

\begin{tabular}{|c|c|c|}
\hline Oxide & Cluster 2 & Cluster 4 \\
\hline $\mathrm{Al}_{2} \mathrm{O}_{3}$ & 23.096 & 14.616 \\
\hline $\mathrm{BaO}$ & 0.211 & 0.251 \\
\hline $\mathrm{CaO}$ & 2.627 & 3.257 \\
\hline $\mathrm{Ce}_{2} \mathrm{O}_{3}$ & 0.554 & 0.583 \\
\hline $\mathrm{Cr}_{2} \mathrm{O}_{3}$ & 0.266 & 0.341 \\
\hline $\mathrm{CuO}$ & 0.081 & 0.105 \\
\hline $\mathrm{Fe}_{2} \mathrm{O}_{3}$ & 30.807 & 35.170 \\
\hline $\mathrm{K}_{2} \mathrm{O}$ & 0.182 & 0.228 \\
\hline $\mathrm{La}_{2} \mathrm{O}_{3}$ & 0.199 & 0.218 \\
\hline $\mathrm{MgO}$ & 0.411 & 0.466 \\
\hline $\mathrm{MnO}$ & 3.996 & 5.172 \\
\hline $\mathrm{Na}_{2} \mathrm{O}$ & 20.251 & 21.209 \\
\hline $\mathrm{NiO}$ & 1.159 & 1.277 \\
\hline $\mathrm{PbO}$ & 0.240 & 0.255 \\
\hline $\mathrm{SO}_{4}$ & 0.200 & 0.252 \\
\hline $\mathrm{SiO}_{2}$ & 3.351 & 5.092 \\
\hline $\mathrm{ThO}_{2}$ & 1.005 & 1.205 \\
\hline $\mathrm{TiO}_{2}$ & 3.293 & 2.771 \\
\hline $\mathrm{U}_{3} \mathrm{O}_{8}$ & 7.441 & 6.758 \\
\hline $\mathrm{ZnO}$ & 0.125 & 0.162 \\
\hline $\mathrm{ZrO}_{2}$ & 0.505 & 0.614 \\
\hline
\end{tabular}

Table 2. Cluster 2 Average and Cluster 4 Average MAR Results

\begin{tabular}{||c|c|c|c|c||}
\hline \% & Frit Composition & Sludge & \multicolumn{2}{|c||}{ MAR Results } \\
\cline { 5 - 5 } WL & (wt\% oxide) & Identifier & with $\mathrm{U}_{3} \mathrm{O}_{8}$ and $\mathrm{ThO}_{2}$ & without $\mathrm{U}_{3} \mathrm{O}_{8}$ and $\mathrm{ThO}_{2}$ \\
\hline 45 & B-14;Li-9;Na-1;Si-76 & Cluster 2 avg & TL & TL \\
\hline 50 & B-14;Li-9;Na-1;Si-76 & Cluster 2 avg & TL & TL \\
\hline 45 & B-18;Li-8;Na-1;Si-73 & Cluster 2 avg & TL & TL \\
\hline 50 & B-18;Li-8;Na-1;Si-73 & Cluster 2 avg & TL & TL \\
\hline 45 & B-14;Li-9;Na-1;Si-76 & Cluster 4 avg & TL & TL \\
\hline 50 & B-14;Li-9;Na-1;Si-76 & Cluster 4 avg & TL lvisc & TL lvisc \\
\hline 45 & B-9;Li-9;Na-4;Si-78 & Cluster 4 avg & TL & TL \\
\hline 50 & B-9;Li-9;Na-4;Si-78 & Cluster 4 avg & TL lvisc & TL lvisc \\
\hline
\end{tabular}

$\mathrm{TL}=$ liquidus temperature and lvisc $=$ low viscosity 


\subsection{Glass Systems for Coupled Operations Showing Select WL Restrictions}

Peeler et al. have provided an assessment of the potential impacts of the options for coupled operations on the projected operating windows for DWPF. ${ }^{7}$ This effort was a paper study that evaluated the impact of auxiliary streams either from crystalline silicotitanate (CST) or from resorcinol formaldehyde (RF) operations for Enhanced Processing Radionuclide Removal (EPRR) on DWPF operation. ${ }^{8}$ Sludge projections for coupled operations compose another important category of future sludge batches anticipated for DWPF. Glass systems involving two specific sludge compositions, MSP-001/SB8 and MSP-001/SB9, from the paper study of Peeler et al. (representing projections of SB8 and SB9, respectively), were of interest to the glass selection process for this task. Peeler et al. ${ }^{7}$ identified two primary issues for these coupled operations flowsheets: (1) the need to demonstrate that higher $\mathrm{TiO}_{2}$ levels (above $2 \mathrm{wt} \%$ ) in DWPF glass pose no issues in regards to $\mathrm{TiO}_{2}$ solubility nor to the applicability of the current $\mathrm{T}_{\mathrm{L}}$ model and (2) the replacement of the homogeneity and associated constraints by the alkali and/or alumina constraints as recommended for sludgeonly processing by Herman et al. ${ }^{9}$ The nominal sludge batch compositions of MSP-001/SB8 and MSP-001/SB9 are listed in Table 3. In the current study, glasses were chosen to address these issues as indicated by the MAR results summarized in Table 4. Note that the MAR results are summarized for glasses with and without $\mathrm{U}_{3} \mathrm{O}_{8}$ and $\mathrm{ThO}_{2}$.

For all twelve glasses (both with and without $\mathrm{U}_{3} \mathrm{O}_{8}$ ), $\mathrm{TiO}_{2}$ concentrations exceed the $2 \mathrm{wt} \%$ limit over which the current $\mathrm{T}_{\mathrm{L}}$ model was developed even at WLs as low as $32 \%$. Fabrication and testing of the non-radioactive glasses would provide insight into $\mathrm{TiO}_{2}$ solubility and $\mathrm{T}_{\mathrm{L}}$ model applicability for coupled operations. In addition, two of the higher $\mathrm{B}_{2} \mathrm{O}_{3}$ based glasses at the higher WLs are predicted to fail $\mathrm{T}_{\mathrm{L}}$. Fabrication and characterization of these glasses could also provide supplemental data and incentive to pursue alternative melter technologies or process control strategies. These data would also add to the limited composition - property database from which models may need to be developed or revised as discussed in Section 3.1. Because the MAR results for $\mathrm{T}_{\mathrm{L}}$ and $\mathrm{TiO}_{2}$ are not affected by the removal of $\mathrm{U}_{3} \mathrm{O}_{8}$ and $\mathrm{ThO}_{2}$, all twelve glasses will be fabricated and characterized, targeting the non-radioactive compositions.

The MAR assessments do suggest that renormalization of the glasses without $\mathrm{U}_{3} \mathrm{O}_{8}$ and $\mathrm{ThO}_{2}$ compromises the ability to challenge the homogeneity and low frit constraints. In order to address these issues, 6 additional glasses will be fabricated with $\mathrm{U}_{3} \mathrm{O}_{8}$ and $\mathrm{ThO}_{2}{ }^{\mathrm{g}}$. It should be noted that low frit and homogeneity are technical issues that occur at relatively low WLs for coupled operations $(35-37 \%$ WL). The ability to identify and address any technical issues resulting from coupled operations at such an early stage will provide the opportunity to develop a technically defensible strategy to ensure that acceptable WLs can be targeted.

\footnotetext{
${ }^{\mathrm{g}}$ While these glasses were not discussed in the original task plan (WSRC-STI-2007-00483), only the chemical compositions and Product Consistency Test (PCT) responses will be measured using the same protocols meeting RW-0333P requirements.
} 
WSRC-STI-2007-00652

Revision 0

Table 3. Nominal Sludge Compositions of MSP-001/SB8 and MSP-001/SB9 (wt\%)

\begin{tabular}{||c|c|c||}
\hline \hline Oxide & MSP-001/SB8 & MSP-001/SB9 \\
\hline $\mathrm{Al}_{2} \mathrm{O}_{3}$ & 12.62 & 11.83 \\
\hline $\mathrm{BaO}$ & 0.22 & 0.21 \\
\hline $\mathrm{CaO}$ & 2.45 & 2.73 \\
\hline $\mathrm{Ce}_{2} \mathrm{O}_{3}$ & 0.52 & 0.71 \\
\hline $\mathrm{Cr}_{2} \mathrm{O}_{3}$ & 0.28 & 0.26 \\
\hline $\mathrm{CuO}$ & 0.08 & 0.07 \\
\hline $\mathrm{Fe}_{2} \mathrm{O}_{3}$ & 29.16 & 32.96 \\
\hline $\mathrm{K}_{2} \mathrm{O}$ & 0.18 & 0.17 \\
\hline $\mathrm{La}_{2} \mathrm{O}_{3}$ & 0.19 & 0.24 \\
\hline $\mathrm{MgO}_{9}$ & 0.40 & 0.45 \\
\hline $\mathrm{MnO}$ & 9.41 & 7.11 \\
\hline $\mathrm{Na}_{2} \mathrm{O}$ & 20.45 & 21.07 \\
\hline $\mathrm{Nb}_{2} \mathrm{O}_{3}$ & 2.27 & 1.66 \\
\hline $\mathrm{NiO} \mathrm{O}$ & 1.88 & 0.94 \\
\hline $\mathrm{PbO} \mathrm{O}$ & 0.31 & 0.36 \\
\hline $\mathrm{SO}_{4}$ & 0.00 & 0.00 \\
\hline $\mathrm{SiO}_{2}$ & 5.44 & 5.04 \\
\hline $\mathrm{ThO}_{2}$ & 2.73 & 2.66 \\
\hline $\mathrm{TiO}_{2}$ & 6.57 & 8.34 \\
\hline $\mathrm{U}_{3} \mathrm{O}_{8}$ & 2.57 & 1.33 \\
\hline $\mathrm{ZnO}_{2 n O}$ & 0.10 & 0.07 \\
\hline $\mathrm{ZrO}_{2}$ & 2.17 & 1.76 \\
\hline \hline
\end{tabular}

Table 4. MSP-001/SB8 and MSP-001/SB9 MAR Results

\begin{tabular}{|c|c|c|c|c|}
\hline \multirow{2}{*}{$\begin{array}{l}\% \\
\text { WL }\end{array}$} & \multirow{2}{*}{ Frit Composition (wt\% oxide) } & \multirow{2}{*}{$\begin{array}{c}\text { Sludge } \\
\text { Identifier }\end{array}$} & \multicolumn{2}{|c|}{ MAR Results } \\
\hline & & & with $\mathrm{U}_{3} \mathrm{O}_{8}$ and $\mathrm{ThO}_{2}$ & without $\mathrm{U}_{3} \mathrm{O}_{8}$ and $\mathrm{ThO}_{2}$ \\
\hline 35 & B-18;Li-8;Na-1;Si-73 & MSP-001 / SB8 & TiO2 Homg & $\mathrm{TiO} 2$ \\
\hline 40 & B-18;Li-8;Na-1;Si-73 & MSP-001 / SB8 & $\mathrm{TiO} 2$ & $\mathrm{TiO} 2$ \\
\hline 45 & B-18;Li-8;Na-1;Si-73 & MSP-001 / SB8 & TL TiO2 & TL TiO2 \\
\hline 35 & B-8;Li-8;Na-8;Si-76 (Frit 418) & MSP-001 / SB8 & TiO2 Homg & $\mathrm{TiO} 2$ \\
\hline 40 & B-8;Li-8;Na-8;Si-76 (Frit 418) & MSP-001 / SB8 & $\mathrm{TiO} 2$ & $\mathrm{TiO} 2$ \\
\hline 45 & B-8;Li-8;Na-8;Si-76 (Frit 418) & MSP-001 / SB8 & $\mathrm{TiO} 2$ & $\mathrm{TiO} 2$ \\
\hline 32 & B-18;Li-6;Na-1;Si-75 & MSP-001 / SB9 & TiO2 Homg & $\mathrm{TiO} 2$ \\
\hline 37 & B-18;Li-6;Na-1;Si-75 & MSP-001 / SB9 & TiO2 1Frit & $\mathrm{TiO} 2$ \\
\hline 42 & B-18;Li-6;Na-1;Si-75 & MSP-001 / SB9 & TL TiO2 & TL TiO2 \\
\hline 32 & B-8;Li-8;Na-8;Si-76 (Frit 418) & MSP-001 / SB9 & TiO2 Homg & $\mathrm{TiO} 2$ \\
\hline 37 & B-8;Li-8;Na-8;Si-76 (Frit 418) & MSP-001 / SB9 & TiO2 1Frit & $\mathrm{TiO} 2$ \\
\hline 42 & B-8;Li-8;Na-8;Si-76 (Frit 418) & MSP-001 / SB9 & $\mathrm{TiO} 2$ & $\mathrm{TiO} 2$ \\
\hline
\end{tabular}

$\mathrm{TiO} 2=\mathrm{TiO}_{2}$ limit, $\mathrm{TL}=$ liquidus temperature, Homg = homogeneity,

1 Frit $=$ low concentration of frit components 
In addition to addressing the specific technical issues of $\mathrm{TiO}_{2}, \mathrm{~T}_{\mathrm{L}}$, low frit, and/or homogeneity, use of "low" and "high" $\mathrm{B}_{2} \mathrm{O}_{3}$ concentration frits will provide a link to frit development efforts for higher Al-based sludges and the SMR task as higher $\mathrm{B}_{2} \mathrm{O}_{3}$ concentration frits are being assessed for improved melt rates. The data from this study can and will be leveraged with other DWPF related programs as well as glass formulation activities for Hanford.

\subsection{Glass Systems with WL Restrictions due to High $\mathrm{Al}_{2} \mathrm{O}_{3}$ Content}

In support of the SMR task, LWO provided fourteen sludge batch compositions without Aldissolution that could be processed at DWPF in the future. ${ }^{6}$ For the current task, the sludge batch projection with the highest alumina content would provide the opportunity to assess issues associated with higher WLs for higher Al-based sludges, assuming that Al-dissolution was not implemented or at least bounding even if low temperature Al-dissolution was utilized. Predictions of nepheline formation have limited the ability to increase WLs for high Al-based sludges and in some instances high Fe-based systems. ${ }^{10,11}$ Recent assessments have suggested that the current nepheline discriminator (limiting value of 0.62 ) is conservative with respect to some compositional fields. For example, glasses containing up to $\sim 26 \mathrm{wt} \%$ $\mathrm{Al}_{2} \mathrm{O}_{3}$ with a nepheline discriminator value of 0.4 have been fabricated and characterized. Results indicate that the PCT responses ${ }^{12}$ for both quenched and centerline canister cooled (CCC) based thermal heat treatments are acceptable. Fox et al. suggest that increased boron content in the frit may suppress nepheline formation, ${ }^{13}$ which is the basis for the frit selection in this task.

A review of the 14 sludge batches without Al-dissolution indicates that SB19 has a projected $\mathrm{Al}_{2} \mathrm{O}_{3}$ concentration of $\sim 35 \mathrm{wt} \%$ (calcined oxides in sludge), which is the highest $\mathrm{Al}_{2} \mathrm{O}_{3}$ content among all projections. ${ }^{6}$ The SB19 nominal sludge composition is given in Table 5. The MAR results of glass compositions derived from this sludge composition and a candidate frit that allows access to relatively high WLs are shown in Table 6. At WLs of $50 \%$ and $55 \%$, these glasses only fail the nepheline constraint. If upon fabrication these glasses that do not contain nepheline, the results would add supplemental data indicating that there is conservatism in the current nepheline discriminator that may limit access to higher WLs for higher Al-based glasses. ${ }^{\text {h }}$ Given the MAR results do not change with the removal of $\mathrm{U}_{3} \mathrm{O}_{8}$ and $\mathrm{ThO}_{2}$, these two glasses will be produced without these two radioactive components.

\footnotetext{
${ }^{\mathrm{h}}$ The predicted nepheline discriminator values for these glasses are 0.56 and 0.52 , respectively.
} 
Table 5. Nominal SB19 Sludge Composition (wt\%)

\begin{tabular}{|c|c|}
\hline Oxide & $\overline{\text { SB19 }}$ \\
\hline $\mathrm{Al}_{2} \mathrm{O}_{3}$ & 34.31 \\
\hline $\mathrm{BaO}$ & 0.18 \\
\hline $\mathrm{CaO}$ & 2.84 \\
\hline $\mathrm{Ce}_{2} \mathrm{O}_{3}$ & 0.20 \\
\hline $\mathrm{Cr}_{2} \mathrm{O}_{3}$ & 0.32 \\
\hline $\mathrm{CuO}$ & 0.09 \\
\hline $\mathrm{Fe}_{2} \mathrm{O}_{3}$ & 18.71 \\
\hline $\mathrm{K}_{2} \mathrm{O}$ & 0.21 \\
\hline $\mathrm{La}_{2} \mathrm{O}_{3}$ & 0.11 \\
\hline $\mathrm{MgO}$ & 0.38 \\
\hline $\mathrm{MnO}$ & 1.79 \\
\hline $\mathrm{Na}_{2} \mathrm{O}$ & 27.85 \\
\hline $\mathrm{NiO}$ & 0.32 \\
\hline $\mathrm{PbO}$ & 0.07 \\
\hline $\mathrm{SO}_{4}$ & 0.17 \\
\hline $\mathrm{SiO}_{2}$ & 8.27 \\
\hline $\mathrm{ThO}_{2}$ & 0.00 \\
\hline $\mathrm{TiO}_{2}$ & 3.10 \\
\hline $\mathrm{U}_{3} \mathrm{O}_{8}$ & 0.54 \\
\hline $\mathrm{ZnO}$ & 0.09 \\
\hline $\mathrm{ZrO}_{2}$ & 0.47 \\
\hline
\end{tabular}

Table 6. Without Aluminum Dissolution WOALD - SB19 MAR Results

\begin{tabular}{||c|c|c|c|c||}
\hline \hline$\%$ & \multirow{2}{*}{$\begin{array}{c}\text { Frit Composition } \\
\text { WL }\end{array}$} & Sludge & \multicolumn{2}{|c|}{ MAR Results } \\
\cline { 4 - 5 } & $(\mathrm{wt} \%$ oxide $)$ & Identifier & with $\mathrm{U}_{3} \mathrm{O}_{8}$ and $\mathrm{ThO}_{2}$ & without $\mathrm{U}_{3} \mathrm{O}_{8}$ and $\mathrm{ThO}_{2}$ \\
\hline 50 & B-18;Li-8;Na-1;Si-73 & WOALD - SB19 & Neph & Neph \\
\hline 55 & B-18;Li-8;Na-1;Si-73 & WOALD - SB19 & Neph & Neph \\
\hline
\end{tabular}

Neph $=$ nepheline discriminator 


\subsection{Specific Glass Compositions}

Based on the selection strategy outlined above, 28 glasses have been identified to address the specific technical issues described in this report. Table 7 and Table 8 summarize the target compositions for the 22 non-radioactive glasses of this study. Table 9 summarizes the six radioactive glasses of this study that focus on the issues of low frit and homogeneity for coupled operations. All 22 non-radioactive glasses will be fabricated and characterized based on the protocols outlined in the SRNL Task and QA plan. ${ }^{4}$ For the six radioactive glasses, the primary focus will be on the PCT response as it relates to the constraints associated with homogeneity. The results of this study will be presented in a subsequent report.

Results of this task will not solve the technical issues being studied, but will:

1. Identify possible solutions to pursue,

2. Add data to the composition - property relationship database that may be necessary for future model development activities, and/or

3. Identify conservatism in the current control strategies from which alternative approaches could be developed to allow for higher WLs to be targeted. 
Table 7. Non-Radioactive Compositions (wt percent) of Test Matrix 2 Glasses

\begin{tabular}{|c|c|c|c|c|c|c|c|c|c|c|c|}
\hline \multirow{3}{*}{$\begin{array}{c}\text { Sludge } \\
\text { Frit } \\
\text { WL (\%) }\end{array}$} & \multicolumn{4}{|c|}{ Cluster 2 avg } & \multicolumn{4}{|c|}{ Cluster 4 avg } & \multirow{2}{*}{\multicolumn{3}{|c|}{$\begin{array}{c}\text { MSP-001 / SB8 } \\
\text { B-18;Li-8;Na-1;Si-73 }\end{array}$}} \\
\hline & \multicolumn{2}{|c|}{ B-14;Li-9;Na-1;Si-76 } & \multicolumn{2}{|c|}{ B-18;Li-8;Na-1;Si-73 } & \multicolumn{2}{|c|}{ B-14;Li-9;Na-1;Si-76 } & \multicolumn{2}{|c|}{ B-9;Li-9;Na-4;Si-78 } & & & \\
\hline & 45 & 50 & 45 & 50 & 45 & 50 & 45 & 50 & 35 & 40 & 45 \\
\hline Glass ID & HWL-01 & HWL-02 & HWL-03 & HWL-04 & HWL-05 & HWL-06 & HWL-07 & HWL-08 & HWL-09 & HWL-10 & HWL-11 \\
\hline $\mathrm{Al} 2 \mathrm{O} 3$ & 10.80 & 12.06 & 10.80 & 12.06 & 6.82 & 7.61 & 6.82 & 7.61 & 4.50 & 5.16 & 5.82 \\
\hline $\mathrm{B} 2 \mathrm{O} 3$ & 8.00 & 7.31 & 10.29 & 9.40 & 7.99 & 7.29 & 5.13 & 4.69 & 11.92 & 11.03 & 10.14 \\
\hline $\mathrm{BaO}$ & 0.10 & 0.11 & 0.10 & 0.11 & 0.12 & 0.13 & 0.12 & 0.13 & 0.08 & 0.09 & 0.10 \\
\hline $\mathrm{CaO}$ & 1.23 & 1.37 & 1.23 & 1.37 & 1.52 & 1.70 & 1.52 & 1.70 & 0.87 & 1.00 & 1.13 \\
\hline $\mathrm{Ce} 2 \mathrm{O} 3$ & 0.26 & 0.29 & 0.26 & 0.29 & 0.27 & 0.30 & 0.27 & 0.30 & 0.19 & 0.21 & 0.24 \\
\hline $\mathrm{Cr} 2 \mathrm{O} 3$ & 0.12 & 0.14 & 0.12 & 0.14 & 0.16 & 0.18 & 0.16 & 0.18 & 0.10 & 0.11 & 0.13 \\
\hline $\mathrm{CuO}$ & 0.04 & 0.04 & 0.04 & 0.04 & 0.05 & 0.05 & 0.05 & 0.05 & 0.03 & 0.03 & 0.04 \\
\hline $\mathrm{Fe} 2 \mathrm{O} 3$ & 14.41 & 16.08 & 14.41 & 16.08 & 16.41 & 18.31 & 16.41 & 18.31 & 10.40 & 11.92 & 13.44 \\
\hline $\mathrm{K} 2 \mathrm{O}$ & 0.09 & 0.10 & 0.09 & 0.10 & 0.11 & 0.12 & 0.11 & 0.12 & 0.06 & 0.07 & 0.08 \\
\hline $\mathrm{La} 2 \mathrm{O} 3$ & 0.09 & 0.10 & 0.09 & 0.10 & 0.10 & 0.11 & 0.10 & 0.11 & 0.07 & 0.08 & 0.09 \\
\hline $\mathrm{Li} 2 \mathrm{O}$ & 5.15 & 4.70 & 4.57 & 4.18 & 5.13 & 4.69 & 5.13 & 4.69 & 5.30 & 4.90 & 4.51 \\
\hline $\mathrm{MgO}$ & 0.19 & 0.21 & 0.19 & 0.21 & 0.22 & 0.24 & 0.22 & 0.24 & 0.14 & 0.16 & 0.18 \\
\hline $\mathrm{MnO}$ & 1.87 & 2.09 & 1.87 & 2.09 & 2.41 & 2.69 & 2.41 & 2.69 & 3.36 & 3.85 & 4.34 \\
\hline $\mathrm{Na} 2 \mathrm{O}$ & 10.04 & 11.09 & 10.04 & 11.09 & 10.47 & 11.56 & 12.18 & 13.13 & 7.96 & 8.97 & 9.99 \\
\hline $\mathrm{Nb} 2 \mathrm{O} 3$ & 0.00 & 0.00 & 0.00 & 0.00 & 0.00 & 0.00 & 0.00 & 0.00 & 0.81 & 0.93 & 1.05 \\
\hline $\mathrm{NiO}$ & 0.54 & 0.61 & 0.54 & 0.61 & 0.60 & 0.66 & 0.60 & 0.66 & 0.67 & 0.77 & 0.87 \\
\hline $\mathrm{PbO}$ & 0.11 & 0.13 & 0.11 & 0.13 & 0.12 & 0.13 & 0.12 & 0.13 & 0.11 & 0.13 & 0.14 \\
\hline $\mathrm{SO} 4$ & 0.09 & 0.10 & 0.09 & 0.10 & 0.12 & 0.13 & 0.12 & 0.13 & 0.00 & 0.00 & 0.00 \\
\hline $\mathrm{SiO} 2$ & 45.02 & 41.42 & 43.30 & 39.86 & 45.73 & 42.23 & 46.87 & 43.27 & 50.29 & 46.97 & 43.64 \\
\hline $\mathrm{TiO} 2$ & 1.54 & 1.72 & 1.54 & 1.72 & 1.29 & 1.44 & 1.29 & 1.44 & 2.34 & 2.69 & 3.03 \\
\hline $\mathrm{ZnO}$ & 0.06 & 0.07 & 0.06 & 0.07 & 0.08 & 0.08 & 0.08 & 0.08 & 0.04 & 0.04 & 0.05 \\
\hline $\mathrm{ZrO} 2$ & 0.24 & 0.26 & 0.24 & 0.26 & 0.29 & 0.32 & 0.29 & 0.32 & 0.77 & 0.89 & 1.00 \\
\hline Total & 100.00 & 100.00 & 100.00 & 100.00 & 100.00 & 100.00 & 100.00 & 100.00 & 100.00 & 100.00 & 100.00 \\
\hline
\end{tabular}


Table 8. Non-Radioactive Compositions (wt percent) of Test Matrix 2 Glasses

\begin{tabular}{|c|c|c|c|c|c|c|c|c|c|c|c|}
\hline \multirow{3}{*}{$\begin{array}{c}\text { Sludge } \\
\text { Frit } \\
\text { WL (\%) } \\
\end{array}$} & \multirow{2}{*}{\multicolumn{3}{|c|}{$\begin{array}{l}\text { MSP-001 / SB8 } \\
\text {-8;Na-8;Si-76 (Frit 418) }\end{array}$}} & \multicolumn{6}{|c|}{ MSP-001 / SB9 } & \multirow{2}{*}{\multicolumn{2}{|c|}{$\begin{array}{c}\text { WOALD - SB19 } \\
\text { B-18;Li-8;Na-1;Si-73 }\end{array}$}} \\
\hline & & & & B-1 & Li-6;Na-1 & $i-75$ & B-8; Li-8 & $\mathrm{Na-8;Si-76}$ & Frit 418) & & \\
\hline & 35 & 40 & 45 & 32 & 37 & 42 & 32 & 37 & 42 & 50 & 55 \\
\hline Glass ID & HWL-12 & HWL-13 & HWL-14 & HWL-15 & HWL-16 & HWL-17 & HWL-18 & HWL-19 & HWL-20 & HWL-21 & HWL-22 \\
\hline $\mathrm{Al} 2 \mathrm{O} 3$ & 4.50 & 5.16 & 5.82 & 3.83 & 4.44 & 5.05 & 3.83 & 4.44 & 5.05 & 17.20 & 18.93 \\
\hline $\mathrm{B} 2 \mathrm{O} 3$ & 5.30 & 4.90 & 4.51 & 12.40 & 11.51 & 10.62 & 5.51 & 5.12 & 4.72 & 9.02 & 8.12 \\
\hline $\mathrm{BaO}$ & 0.08 & 0.09 & 0.10 & 0.07 & 0.08 & 0.09 & 0.07 & 0.08 & 0.09 & 0.09 & 0.10 \\
\hline $\mathrm{CaO}$ & 0.87 & 1.00 & 1.13 & 0.89 & 1.03 & 1.17 & 0.89 & 1.03 & 1.17 & 1.42 & 1.57 \\
\hline $\mathrm{Ce} 2 \mathrm{O} 3$ & 0.19 & 0.21 & 0.24 & 0.23 & 0.27 & 0.30 & 0.23 & 0.27 & 0.30 & 0.10 & 0.11 \\
\hline $\mathrm{Cr} 2 \mathrm{O} 3$ & 0.10 & 0.11 & 0.13 & 0.08 & 0.10 & 0.11 & 0.08 & 0.10 & 0.11 & 0.16 & 0.18 \\
\hline $\mathrm{CuO}$ & 0.03 & 0.03 & 0.04 & 0.02 & 0.03 & 0.03 & 0.02 & 0.03 & 0.03 & 0.04 & 0.05 \\
\hline $\mathrm{Fe} 2 \mathrm{O} 3$ & 10.40 & 11.92 & 13.44 & 10.68 & 12.38 & 14.08 & 10.68 & 12.38 & 14.08 & 9.38 & 10.32 \\
\hline $\mathrm{K} 2 \mathrm{O}$ & 0.06 & 0.07 & 0.08 & 0.05 & 0.06 & 0.07 & 0.05 & 0.06 & 0.07 & 0.11 & 0.12 \\
\hline $\mathrm{La} 2 \mathrm{O} 3$ & 0.07 & 0.08 & 0.09 & 0.08 & 0.09 & 0.10 & 0.08 & 0.09 & 0.10 & 0.05 & 0.06 \\
\hline Li2O & 5.30 & 4.90 & 4.51 & 4.13 & 3.84 & 3.54 & 5.51 & 5.12 & 4.72 & 4.01 & 3.61 \\
\hline $\mathrm{MgO}$ & 0.14 & 0.16 & 0.18 & 0.15 & 0.17 & 0.19 & 0.15 & 0.17 & 0.19 & 0.19 & 0.21 \\
\hline $\mathrm{MnO}$ & 3.36 & 3.85 & 4.34 & 2.31 & 2.67 & 3.04 & 2.31 & 2.67 & 3.04 & 0.90 & 0.99 \\
\hline $\mathrm{Na} 2 \mathrm{O}$ & 12.59 & 13.26 & 13.94 & 7.52 & 8.55 & 9.59 & 12.34 & 13.03 & 13.72 & 14.47 & 15.82 \\
\hline $\mathrm{Nb} 2 \mathrm{O} 3$ & 0.81 & 0.93 & 1.05 & 0.54 & 0.62 & 0.71 & 0.54 & 0.62 & 0.71 & 0.00 & 0.00 \\
\hline $\mathrm{NiO}$ & 0.67 & 0.77 & 0.87 & 0.31 & 0.35 & 0.40 & 0.31 & 0.35 & 0.40 & 0.16 & 0.18 \\
\hline $\mathrm{PbO}$ & 0.11 & 0.13 & 0.14 & 0.12 & 0.14 & 0.15 & 0.12 & 0.14 & 0.15 & 0.04 & 0.04 \\
\hline SO4 & 0.00 & 0.00 & 0.00 & 0.00 & 0.00 & 0.00 & 0.00 & 0.00 & 0.00 & 0.08 & 0.09 \\
\hline $\mathrm{SiO} 2$ & 52.27 & 48.81 & 45.33 & 53.29 & 49.85 & 46.39 & 53.98 & 50.49 & 46.98 & 40.75 & 37.51 \\
\hline $\mathrm{TiO} 2$ & 2.34 & 2.69 & 3.03 & 2.70 & 3.13 & 3.56 & 2.70 & 3.13 & 3.56 & 1.55 & 1.71 \\
\hline $\mathrm{ZnO}$ & 0.04 & 0.04 & 0.05 & 0.02 & 0.03 & 0.03 & 0.02 & 0.03 & 0.03 & 0.05 & 0.05 \\
\hline $\mathrm{ZrO} 2$ & 0.77 & 0.89 & 1.00 & 0.57 & 0.66 & 0.75 & 0.57 & 0.66 & 0.75 & 0.24 & 0.26 \\
\hline Total & 100.00 & 100.00 & 100.00 & 100.00 & 100.00 & 100.00 & 100.00 & 100.00 & 100.00 & 100.00 & 100.00 \\
\hline
\end{tabular}


Table 9. Radioactive Compositions (wt percent) of Test Matrix 2 Glasses

\begin{tabular}{|c|c|c|c|c|c|c|}
\hline Sludge & \multicolumn{2}{|c|}{ MSP-001 / SB8 } & \multicolumn{4}{|c|}{ MSP-001 / SB9 } \\
\hline Frit & B-18;Li-8;Na-1;Si-73 & B-8;Li-8;Na-8;Si-76 (Frit 418) & B-18;L & $1 ; \mathrm{Si}-75$ & B-8;Li-8;Na & 6 (Frit 418) \\
\hline WL (\%) & 35 & 35 & 32 & 37 & 32 & 37 \\
\hline Glass ID & HWL-23 & HWL-24 & HWL-25 & HWL-26 & HWL-27 & HWL-28 \\
\hline $\mathrm{Al} 2 \mathrm{O} 3$ & 4.42 & 4.42 & 3.79 & 4.38 & 3.79 & 4.38 \\
\hline $\mathrm{B} 2 \mathrm{O} 3$ & 11.70 & 5.20 & 12.24 & 11.34 & 5.44 & 5.04 \\
\hline $\mathrm{BaO}$ & 0.08 & 0.08 & 0.07 & 0.08 & 0.07 & 0.08 \\
\hline $\mathrm{CaO}$ & 0.86 & 0.86 & 0.87 & 1.01 & 0.87 & 1.01 \\
\hline $\mathrm{Cr} 2 \mathrm{O} 3$ & 0.10 & 0.10 & 0.08 & 0.10 & 0.08 & 0.10 \\
\hline $\mathrm{CuO}$ & 0.03 & 0.03 & 0.02 & 0.03 & 0.02 & 0.03 \\
\hline $\mathrm{Fe} 2 \mathrm{O} 3$ & 10.21 & 10.21 & 10.55 & 12.19 & 10.55 & 12.19 \\
\hline $\mathrm{K} 2 \mathrm{O}$ & 0.06 & 0.06 & 0.05 & 0.06 & 0.05 & 0.06 \\
\hline La2O3 & 0.07 & 0.07 & 0.08 & 0.09 & 0.08 & 0.09 \\
\hline $\mathrm{Li} 2 \mathrm{O}$ & 5.20 & 5.20 & 4.08 & 3.78 & 5.44 & 5.04 \\
\hline $\mathrm{MgO}$ & 0.14 & 0.14 & 0.15 & 0.17 & 0.15 & 0.17 \\
\hline $\mathrm{Na} 2 \mathrm{O}$ & 7.81 & 12.36 & 7.42 & 8.43 & 12.18 & 12.84 \\
\hline $\mathrm{Nb} 2 \mathrm{O} 3$ & 0.79 & 0.79 & 0.53 & 0.61 & 0.53 & 0.61 \\
\hline $\mathrm{NiO}$ & 0.66 & 0.66 & 0.30 & 0.35 & 0.30 & 0.35 \\
\hline $\mathrm{PbO}$ & 0.11 & 0.11 & 0.12 & 0.13 & 0.12 & 0.13 \\
\hline SO4 & 0.00 & 0.00 & 0.00 & 0.00 & 0.00 & 0.00 \\
\hline $\mathrm{SiO} 2$ & 49.35 & 51.30 & 52.61 & 49.11 & 53.29 & 49.74 \\
\hline ThO2 & 0.96 & 0.96 & 0.85 & 0.99 & 0.85 & 0.99 \\
\hline $\mathrm{TiO} 2$ & 2.30 & 2.30 & 2.67 & 3.09 & 2.67 & 3.09 \\
\hline U3O8 & 0.90 & 0.90 & 0.43 & 0.49 & 0.43 & 0.49 \\
\hline $\mathrm{ZnO}$ & 0.04 & 0.04 & 0.02 & 0.03 & 0.02 & 0.03 \\
\hline $\mathrm{ZrO} 2$ & 0.76 & 0.76 & 0.56 & 0.65 & 0.56 & 0.65 \\
\hline Total & 100.00 & 100.00 & 100.00 & 100.00 & 100.00 & 100.00 \\
\hline
\end{tabular}


WSRC-STI-2007-00652

Revision 0

\subsection{References}

1. D. Kim, "EM-21 HLW Glass Studies Test Plan: Crystal Accumulation Modeling Task - Glass Matrix Testing," Pacific Northwest National Laboratory (PNNL), Richland, WA, Report No. EMHLW-TP-07-01, Rev. 0, August 2007.

2. A.P. Kobelev, S.V. Stefanovsky, O.A. Knyazev, T.N. Laschenova, A.G. Ptashkin, M.A. Polkanov, E.W. Holtzscheiter, and J.C. Marra, "Results of a 50\% Waste Loading Vitrification Test Using the Cold Crucible Melter for Savannah River Site Waste," in Results of a 50\% Waste Loading Vitrification Test Using the Cold Crucible Melter for Savannah River Site Waste, Waste Management 2006 Proceedings. Waste Management, Tucson, AZ, February 26-March 2, 2006.

3. K. Gerdes, "Enhanced DOE High-Level Waste Melter Throughput Studies [Work Authorization / Task Change Request (TCR)]," Project Manager at the U.S. Department of Energy Headquarters, Washington, D.C., Report No. Project Number SR071401, May, 2007.

4. F.C. Raszewski, A.S. Choi, T.B. Edwards, K.M. Fox, and M.E. Smith, "Enhanced DOE High-Level Waste Melter Throughput Studies: Task Plan," Savannah River National Laboratory, Aiken, SC, Report No. WSRC-STI-2007-00483, October 2007.

5. J.D. Newell, T.B. Edwards, and D.K. Peeler, "Initial MAR Assessments to Assess the Impact of Al-Dissolution on DWPF Operating Windows," Savannah River National Laboratory, Aiken, SC, Report No. WSRC-STI-2007-00688, Draft.

6. D.K. Peeler, M.E. Smith, M.E. Stone, T.B. Edwards, and J.D. Newell, "Frit Development for High $\mathrm{Al}_{2} \mathrm{O}_{3}$ Based Sludges: Task Technical and Quality Assurance Plan," Savannah River National Laboratory, Aiken, SC, Report No. WSRC-STI2007-00504 Rev. 0, September 2007.

7. D.K. Peeler and T.B. Edwards, "High-Level Review of the Impacts of CST and RF on DWPF Processing: A Glass Formulation Perspective " Savannah River National Laboratory, Aiken, SC, Report No. SRNL-PSE-2007-00177, September 19, 2007.

8. B.A. Hamm, "Impact of Modular Salt Processing on DWPF Sludge Batch Plan," Washington Savannah River Company, Aiken, SC, Report No. LWO-PIT-200700073 Rev. 0, September 2007.

9. C.C. Herman, T.B. Edwards, D.R. Best, D.M. Marsh, and R.J. Workman, "Reduction of Constraints: Phase 2 Experimental Assessment for Sludge-Only Processing," Savannah River National Laboratory, Aiken, SC, Report No. WSRC-TR-2002-00482 Rev. 0, November 2002. 
10. K.M. Fox, T.B. Edwards, D.K. Peeler, D.R. Best, I.A. Reamer, and R.J. Workman, "Durability and Nepheline Crystallization Study for High Level Waste (HLW) Sludge Batch 4 (SB4) Glasses Formulated with Frit 503," Savannah River National Laboratory, Aiken, SC, Report No. WSRC-STI-2006-00009, Revision 0, June 2006.

11. K.M. Fox, T.B. Edwards, D.R. Best, I.A. Reamer, and R.J. Workman, "Sludge Batch 5 (SB5): Selection of Candidate Frits and Characterization of Preliminary Glass Systems," Savannah River National Laboratory, Aiken, SC, Report No. WSRC-STI2007-00418, Rev. 0, July 2007.

12. "Standard Test Methods for Determining Chemical Durability of Nuclear, Hazardous, and Mixed Waste Glasses and Multiphase Glass Ceramics: The Product Consistency Test (PCT)," ASTM International, West Conshohocken, PA, Report No. ASTM C 1285-02, 2002.

13. K.M. Fox and D.K. Peeler, "Demonstration of Very High Aluminum Retention in Simulated HLW Glass," Savannah River National Laboratory, Aiken, SC, Report No. SRNL-PSE-2007-00231 Rev. 0. 


\section{Distribution:}

A.B. Barnes, 999-W

D.B. Burns, 786-5A

A.S. Choi, 773-42A

D.A. Crowley, 999-W

R.E. Edwards, 773-A

T.B. Edwards, 999-W

K.M. Fox, 999-W

C.C. Herman, 999-W

C.M. Janzten, 773-A

J.E. Marra, 773-A

J.D. Newell, 999-W

D.K. Peeler, 999-W

F.C. Raszewski, 999-W

M.E. Smith, 999-W

M.E. Stone, 999-W

P.C. Suggs, 766-H

J.P. Vaughan, 773-41A

A.L. Youchak, 999-W 